\title{
Article \\ Alkali-Activated Binders Using Bottom Ash from Waste-to-Energy Plants and Aluminium Recycling Waste
}

\author{
Alex Maldonado-Alameda (D), Jofre Mañosa (D), Jessica Giro-Paloma ${ }^{(D)}$, Joan Formosa (D) \\ and Josep Maria Chimenos * (D)
}

check for updates

Citation: Maldonado-Alameda, A.; Mañosa, J.; Giro-Paloma, J.; Formosa J.; Chimenos, J.M. Alkali-Activated Binders Using Bottom Ash from Waste-to-Energy Plants and Aluminium Recycling Waste. Appl. Sci. 2021, 11, 3840. https://doi.org/ 10.3390/app11093840

Academic Editors: Fortunato Crea and Sebastiano Candamano

Received: 3 April 2021

Accepted: 20 April 2021

Published: 23 April 2021

Publisher's Note: MDPI stays neutral with regard to jurisdictional claims in published maps and institutional affiliations.

Copyright: (c) 2021 by the authors. Licensee MDPI, Basel, Switzerland. This article is an open access article distributed under the terms and conditions of the Creative Commons Attribution (CC BY) license (https:/ / creativecommons.org/licenses/by/ $4.0 /)$.
Departament de Ciència de Materials i Química Física, Universitat de Barcelona, C/Martí i Franquès, 108028 Barcelona, Spain; alex.maldonado@ub.edu (A.M.-A.); jofremanosa@ub.edu (J.M.); jessicagiro@ub.edu (J.G.-P.); joanformosa@ub.edu (J.F.)

* Correspondence: chimenos@ub.edu; Tel.: +34-93-402-1316

\begin{abstract}
Alkali-activated binders (AABs) stand out as a promising alternative to replace ordinary Portland cement (OPC) due to the possibility of using by-products and wastes in their manufacturing. This paper assessed the potential of weathered bottom ash (WBA) from waste-to-energy plants and PAVAL ${ }^{\circledR}(\mathrm{PV})$, a secondary aluminium recycling process by-product, as precursors of AABs. WBA and PV were mixed at weight ratios of 98/2, 95/5, and 90/10. A mixture of waterglass (WG) and $\mathrm{NaOH}$ at different concentrations (4 and $6 \mathrm{M}$ ) was used as the alkaline activator solution. The effects of increasing $\mathrm{NaOH}$ concentration and PV content were evaluated. Alkali-activated WBA/PV (AA-WBA/PV) binders were obtained. Selective chemical extractions and physicochemical characterization revealed the formation of C-S-H, C-A-S-H, and (N,C)-A-S-H gels. Increasing the $\mathrm{NaOH}$ concentration and PV content increased porosity and reduced compressive strength (25.63 to $12.07 \mathrm{MPa}$ ). The leaching potential of As and $\mathrm{Sb}$ from AA-WBA/PV exceeded the threshold for acceptance in landfills for non-hazardous waste.
\end{abstract}

Keywords: MSWI; weathered bottom ash; aluminium salt slag; alkali-activated materials; waste valorization; by-product

\section{Introduction}

The importance of waste management is increasing every year due to the large amount of residues generated as a result of the increasing population, urbanization, and rising living standards [1]. European Union (EU) countries are channelling their efforts into implementing innovative strategies and policies based on the recycling, re-use, and reduction of residues [2]. The European Waste Framework Directive (2008/98/EC) promotes the search for viable alternatives for waste management and efficient resource use. It also promotes zero-waste policies to mitigate waste management problems. The zero-waste concept is based on an infrastructural change in waste management involving all the manufacturing stages and aiming to transform residues into resources [3]. The goal is to move toward low-carbon zero-waste manufacturing through developing new secondary materials by turning residues into raw materials [4].

Municipal solid waste (MSW) represented around $10 \%$ of the 2.54 billion tonnes of waste generated in the European Union (EU) in 2018 [5,6]. Around 30\% of the MSW is incinerated in waste-to-energy (WtE) plants [5]. MSW incineration (MSWI) can recover energy and reduce landfilling, as well as decrease the mass (70\%) and volume (90\%) of the MSW [7]. Approximately 20\% of the MSWI becomes a product known as incinerator bottom ash (IBA), which is mainly composed of a mineral fraction (80-85 wt. \%), ferrous metals (10-12 wt. \%, mainly steel), and non-ferrous metals (2-5 wt. \%, two-thirds of which is aluminium) [8,9]. IBA is highly heterogeneous and contains potentially leachable soluble salts and heavy metalloids [10]. A natural weathering process that involves storing the IBA outdoors (2-3 months) is necessary to immobilize the heavy metalloids and stabilize $\mathrm{pH}$ 
through the carbonation of the fresh IBA [11]. The resulting material after the weathering process is known as weathered bottom ash (WBA). The particle size distribution and a composition rich in glass, ceramics, stones, bricks, and melting products [12] make the WBA suitable for cement production [13], as aggregates in road construction, concrete, or mortars [14,15], or for the manufacture of ceramic-based products [16]. However, the use of WBA in engineering is limited due to its environmental risks and inferior properties compared to natural aggregates and products. Research on the potential applications of WBA must therefore be focused on those that minimize the leaching potential of heavy metalloids [10]. In this sense, WBA can be used as an aluminosilicate precursor in alkali activation technology, since a cementitious matrix can immobilize heavy metalloids. Some recent studies have demonstrated the potential of WBA as a precursor in the synthesis of alkali-activated cements (AACs) [17-19].

AACs are high-strength binders obtained from the reaction between an aluminosilicaterich solid precursor and an alkaline activator [20]. One of their main advantages is that they can be formulated from aluminosilicate-rich urban, industrial, agro-industrial, and mining wastes $[21,22]$. AACs are an excellent alternative to mitigating the $\mathrm{CO}_{2}$ emissions and energy consumption associated with the production of ordinary Portland cement (OPC) [23]. Hence, the production of AACs can promote suitable waste management and sustainable cement production. Additionally, the properties of the AACs are very promising and comparable to those of OPC [24]. These properties vary depending on the curing temperature [25], the alkaline activator used [26], the $\mathrm{SiO}_{2} / \mathrm{Al}_{2} \mathrm{O}_{3}$ ratio, and the calcium content [27]. The aluminium content plays an essential role in the alkali activation, which affects the nature of the formed products and the strength of the AACs [28,29]. Therefore, the use of aluminium correctors is necessary when the AACs are obtained from the alkali activation of precursors that have a substantial lack of reactive aluminium compared to reactive silica, as is the case with WBA $[17,30]$.

In this study, new sustainable alkali-activated binders (AABs) were obtained from the alkali activation of municipal and industrial waste. The least polluted fraction of WBA ( 8 to $30 \mathrm{~mm}$ ) was used, given that it has the lowest concentrations of heavy metalloids and the highest $\mathrm{SiO}_{2}$ availability [17,31]. Additionally, this fraction allows enhancing the mechanical properties of alkali-activated WBA binders as reported elsewhere by the authors [32]. PAVAL ${ }^{\circledR}(\mathrm{PV})$ was also used as a source of reactive aluminium. PV is an industrial waste generated from the salt slag recovery phase of the secondary aluminium recycling process [33]. This aluminium salt slag is processed to separate PV (mainly composed of aluminium oxides) from metallic aluminium and flux, as well as from scarified salts $(\mathrm{NaCl}$ and $\mathrm{KCl})$ [34]. Recent studies have shown the potential applications of PV in the cement, ceramic, refractory, and building industries [33,35]. The main goal of this study was to formulate AABs using the coarser and least polluted fraction of WBA and PV (AA-WBA/PV) to enhance the mechanical properties of the alkali-activated WBA binders (AA-WBA) obtained previously [36]. The valorization of WBA and PV contributes to the zero-waste principle and low-carbon manufacturing and gives an added value to the final material. Several AA-WBA/PV formulations were developed by mixing WBA and PV at different weight ratios and using a mixture of sodium silicate $\left(\mathrm{Na}_{2} \mathrm{SiO}_{3}\right)$ and sodium hydroxide $(\mathrm{NaOH})$ as the alkaline activator solution. The effects of $\mathrm{PV}$ and the alkaline activator concentration on the AA-WBA/PV binders were also evaluated.

\section{Materials and Methods}

\subsection{Materials}

WBA and PV were used as precursors to prepare the AA-WBA/PV formulations. The WBA was supplied by the VECSA company and collected from a WtE plant located in Tarragona (Spain), which produces $32 \mathrm{kt} \cdot \mathrm{y}^{-1}$. PV was provided by the BEFESA company from its salt slag treatment plant located in Valladolid (Spain), which generates around $90 \mathrm{kt} \cdot \mathrm{y}^{-1}$ of this aluminium salt slag [35]. $\mathrm{Na}_{2} \mathrm{SiO}_{3}$ was supplied by Scharlab, S.L. (Barcelona, Spain), 
while the $\mathrm{NaOH}$ solutions were prepared by dissolving $\mathrm{NaOH}$ pearls (Labbox Labware S.L. (Barcelona, Spain); purity $>98 \%$ ) in deionized water.

The WBA and PV were first dried for $24 \mathrm{~h}$ in a stove at $105^{\circ} \mathrm{C}$. Both materials were then sieved through standard sieves to determine the particle size distribution (PSD) (shown in Figure 1). The shaded area of the WBA in Figure 1 shows the least polluted fraction (8 to $30 \mathrm{~mm}$ ), which was used to formulate the AA-WBA/PV binders. Finally, the WBA and PV were crushed and milled separately until a particle size below $80 \mu \mathrm{m}$ was obtained.

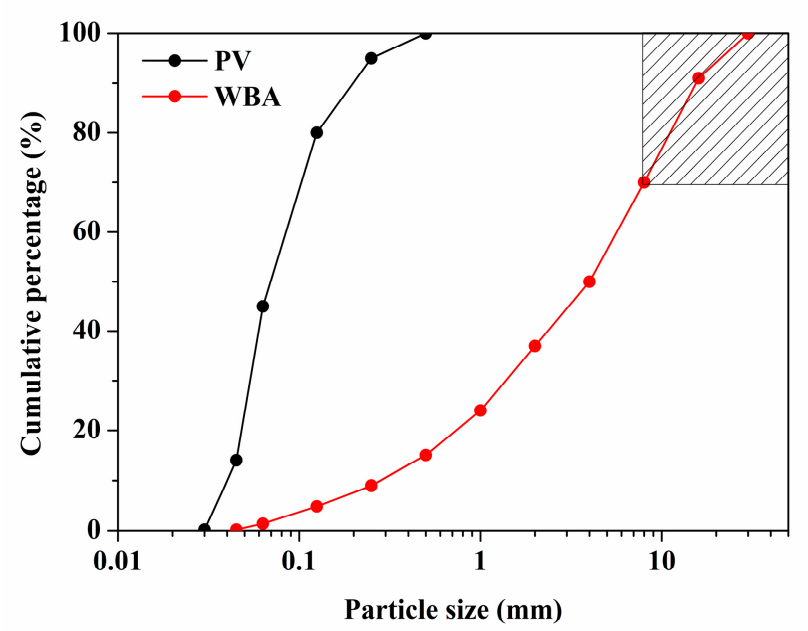

Figure 1. Particle size distribution (PSD) of weathered bottom ash (WBA) and $\mathrm{PAVAL}^{\circledR}(\mathrm{PV})$.

Table 1 shows the chemical compositions of the WBA and PV determined by X-ray fluorescence (XRF) using the Panalytical Philips PW2400 Sequential X-ray spectrophotometer (Malvern Panalytical, Malvern, United Kingdom) equipped with the UniQuant ${ }^{\circledR}$ version 5.0 software. The main oxide compounds identified in the $\mathrm{WBA}$ were $\mathrm{SiO}_{2}, \mathrm{Al}_{2} \mathrm{O}_{3}$, and $\mathrm{CaO}$ from the high levels of glass cullet and fired ceramics in the least polluted fraction [31]. The main oxides found in PV were $\mathrm{SiO}_{2}$ and $\mathrm{Al}_{2} \mathrm{O}_{3}$. Therefore, the WBA and PV were considered potential AABs precursors due to their calcium aluminosilicate-rich nature. Furthermore, these elemental oxides have reactive phases (amorphous $\mathrm{SiO}_{2}$ and $\mathrm{Al}_{2} \mathrm{O}_{3}$ ) to form AABs, as well as unreactive or less reactive phases $\left(\mathrm{SiO}_{2}\right.$ and $\mathrm{Al}_{2} \mathrm{O}_{3}$ crystalline phases) that probably remain inert in the alkali-activation process.

Table 1. Major and minor elements composition of weathered bottom ash (WBA) and PAVAL ${ }^{\circledR}$ (PV) powders.

\begin{tabular}{ccccccccc}
\hline \multicolumn{7}{c}{ WBA (wt. \%) } \\
\hline $\mathrm{SiO}_{2}$ & $\mathrm{CaO}$ & $\mathrm{Al}_{2} \mathrm{O}_{3}$ & $\mathrm{Na}_{2} \mathrm{O}$ & $\mathrm{K}_{2} \mathrm{O}$ & $\mathrm{Fe}_{2} \mathrm{O}_{3}$ & $\mathrm{MgO}$ & $\mathrm{TiO}_{2}$ & LOI $^{\mathbf{1}}$ \\
52.08 & 20.72 & 6.35 & 3.38 & 2.09 & 4.12 & 2.43 & 0.65 & 6.1 \\
\hline \multicolumn{7}{c}{$\mathbf{P V}$ (wt. \%) } \\
\hline $\mathrm{SiO}_{2}$ & $\mathrm{CaO}$ & $\mathrm{Al}_{2} \mathrm{O}_{3}$ & $\mathrm{Na}_{2} \mathrm{O}$ & $\mathbf{K}_{2} \mathrm{O}$ & $\mathrm{Fe}_{2} \mathrm{O}_{3}$ & $\mathbf{M g O}$ & $\mathrm{TiO}_{2}$ & LOI $^{\mathbf{1}}$ \\
7.93 & 2.24 & 61.02 & 3.22 & 0.68 & 2.65 & 4.73 & 0.80 & 15.71 \\
\hline 1
\end{tabular}

${ }^{1}$ Loss on ignition at $1100^{\circ} \mathrm{C}$.

The availability of the reactive phases of the WBA and PV was assessed using different concentrations of $\mathrm{NaOH}$ solution $(4,6$, or $8 \mathrm{M})[17,37]$. These experimental trials consisted of mixing $1 \mathrm{~g}$ of WBA and PV with $100 \mathrm{~mL}$ of the $\mathrm{NaOH}$ solution in a Teflon beaker and stirring for $5 \mathrm{~h}$ at $80^{\circ} \mathrm{C}$. Afterwards, the leached $\mathrm{Si}$ and $\mathrm{Al}$ concentrations were determined by analyzing the resulting filtered solution with inductively coupled plasma optical emission spectrometry (ICP-OES) using the PerkinElmer Optima 3200 RL spectrometer (PerkinElmer Inc., Waltham, MA, USA). The percentages of available $\mathrm{SiO}_{2}$ and $\mathrm{Al}_{2} \mathrm{O}_{3}$ in both the WBA and $\mathrm{PV}$ are plotted in Figure 2. Around $20 \%$ of $\mathrm{SiO}_{2}$ and $3 \%$ of $\mathrm{Al}_{2} \mathrm{O}_{3}$ were available in the WBA, while approximately $2.5-5 \%$ of $\mathrm{SiO}_{2}$ and $35 \%$ of $\mathrm{Al}_{2} \mathrm{O}_{3}$ were available in PV. These 
results indicate that the WBA and PV have the potential to be secondary silica-rich and alumina-rich sources, respectively.

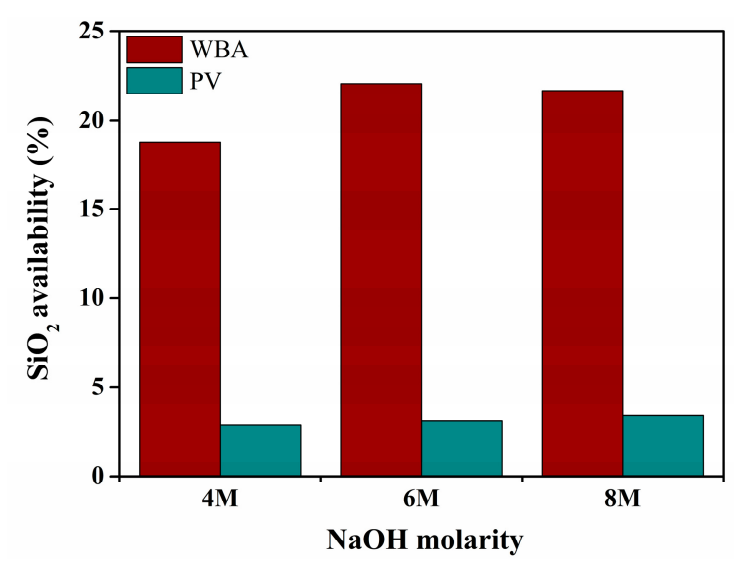

(a)

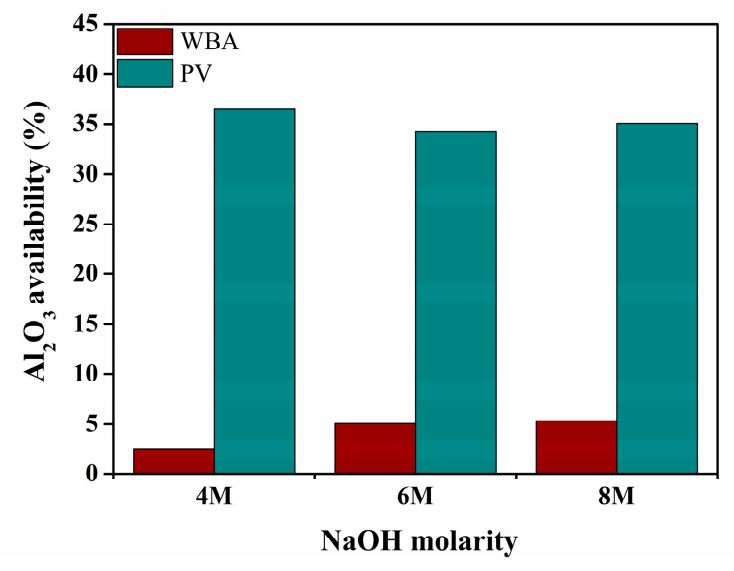

(b)

Figure 2. $\mathrm{SiO}_{2}$ and $\mathrm{Al}_{2} \mathrm{O}_{3}$ availability percentage in (a) WBA and (b) PV samples.

X-ray diffraction (XRD) analysis of the WBA and PV was conducted with a BraggBrentano Siemens D-500 powder diffractometer (Siemens, Munich, Germany) with CuK $\alpha$ radiation. The main crystalline phases detected in the WBA were quartz $\left(\mathrm{SiO}_{2} ; \mathrm{PDF}\right.$ 01-079-1910) and calcite $\left(\mathrm{CaCO}_{3} ; \mathrm{PDF} \#\right.$ 01-083-1762), as shown in Figure 3a. Other minor phases such as dolomite $\left(\mathrm{CaMg}\left(\mathrm{CO}_{3}\right)_{2} ;\right.$ PDF\# 01-075-1759), akermanite $\left(\mathrm{Ca}_{2} \mathrm{Mg}\left(\mathrm{Si}_{2} \mathrm{O}_{7}\right)\right.$; PDF\# 01-079-2424), anhydrite $\left(\mathrm{CaSO}_{4} ; \mathrm{PDF} \#\right.$ 01-072-0503), albite calcian-ordered $\left((\mathrm{Na}, \mathrm{Ca}) \mathrm{Al}(\mathrm{Si}, \mathrm{Al})_{3} \mathrm{O}_{8} ; \mathrm{PDF} \#\right.$ 020-0548), microcline ( $\mathrm{KAlSi}_{3} \mathrm{O}_{8}$; PDF\# 01-076-0918), and muscovite $\left(\mathrm{KAl}_{2}\left(\mathrm{AlSi}_{3} \mathrm{O}_{10}\right)(\mathrm{OH})_{2}\right.$; $\mathrm{PDF}$ 01-077-2255) were also identified.

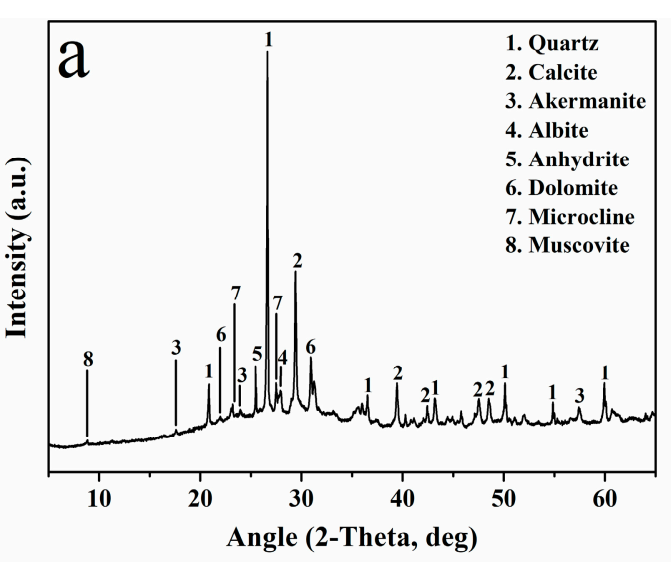

(a)

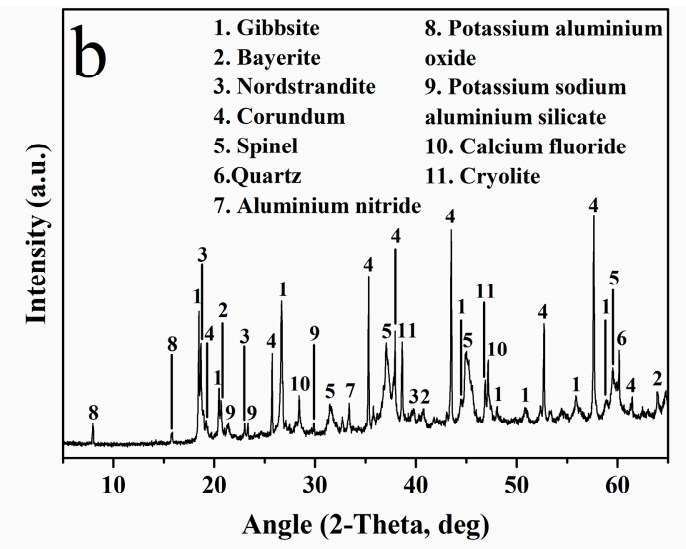

(b)

Figure 3. XRD patterns of (a) WBA and (b) PV.

Gibbsite $\left(\mathrm{Al}(\mathrm{OH})_{3} ; \mathrm{PDF} \#\right.$ 01-070-2038), bayerite $\left(\mathrm{Al}(\mathrm{OH})_{3} ; \mathrm{PDF} \#\right.$ 01-077-0114), nordstrandite $\left(\mathrm{Al}(\mathrm{OH})_{3} ; \mathrm{PDF} \#\right.$ 01-072-0623), corundum $\left(\mathrm{Al}_{2} \mathrm{O}_{3} ; \mathrm{PDF} \#\right.$ 01-071-1123), and spinel $\left(\mathrm{MgAl}_{2} \mathrm{O}_{4} ; \mathrm{PDF}\right.$ 01-077-0435) were detected as the major crystalline phases in PV (Figure 3b). Minor phases such as aluminium nitride (AlN; PDF\# 01-075-1620), potassium sodium aluminium silicate $\left(\mathrm{Al}(\mathrm{K}, \mathrm{Na}) \mathrm{O}_{6} \mathrm{Si}_{2} ; \mathrm{PDF}\right.$ 01-070-1260), potassium aluminium oxide $\left(\mathrm{AlKO}_{2}\right.$; PDF\# 01-084-0380), calcium fluoride $\left(\mathrm{CaF}_{2}\right.$; PDF\# 01-077-0245), cryolite $\left(\mathrm{Na}_{3} \mathrm{AlF}_{6}\right.$; PDF\# 25-0772), and quartz ( $\mathrm{SiO}_{2} ; \mathrm{PDF} \#$ 01-079-1910) were also identified. The XRD results were consistent with those of the XRF analysis, demonstrating the calcium aluminosilicate-rich composition of the WBA and PV. 


\section{2. $A A-W B A / P V$ Preparation}

Table 2 shows the mixture proportion of the AA-WBA/PV formulations, the silicate modulus (Ms) of the alkaline activator solution, and the alkali dosage $\left(\mathrm{Na}_{2} \mathrm{O}\right.$ wt. \%). The weight percentages of the WBA and PV (referred to as solid (S)) varied, while the weight percentage of the alkaline activator (referred to as liquid (L)) was fixed. A mixture of $\mathrm{Na}_{2} \mathrm{SiO}_{3}\left(26.44 \%\right.$ of $\mathrm{SiO}_{2}$ and $8.21 \%$ of $\left.\mathrm{Na}_{2} \mathrm{O} ; \rho=1.37 \mathrm{~g} \cdot \mathrm{cm}^{-3}\right)$ and $\mathrm{NaOH}$ solution $(4$ or $6 \mathrm{M})$ was prepared as the alkaline activator solution. The liquid-to-solid (L/S) mass ratio was fixed (0.6) to maintain good workability of the pastes during the mixing and casting process. The use of $8 \mathrm{M} \mathrm{NaOH}$ solution and the addition of more than $10 \%$ of $\mathrm{PV}$ were discarded, since both excessively increased porosity through the reaction between the aluminium nitride in $\mathrm{PV}$ and $\mathrm{NaOH}$, generating ammonia gas [38].

Table 2. AA-WBA/PV mix proportion.

\begin{tabular}{|c|c|c|c|c|c|c|c|}
\hline \multirow{3}{*}{ Reference } & \multicolumn{2}{|c|}{$S$} & \multicolumn{3}{|c|}{ L } & \multirow{3}{*}{$\mathrm{Na}_{2} \mathrm{O}^{1}$} & \multirow{3}{*}{$\mathrm{SiO}_{2} / \mathrm{Na}_{2} \mathrm{O}^{3}$} \\
\hline & \multirow{2}{*}{ WBA $^{1}$} & \multirow{2}{*}{$\mathbf{P V}^{1}$} & \multicolumn{2}{|c|}{$\mathrm{NaOH}^{2}$} & \multirow{2}{*}{$\mathrm{Na}_{2} \mathrm{SiO}_{3}{ }^{2}$} & & \\
\hline & & & $4 \mathrm{M}$ & $6 \mathrm{M}$ & & & \\
\hline W98-PV2-4M & 98 & 2 & 20 & & 80 & 5.2 & 2.5 \\
\hline W95-PV5-4M & 95 & 5 & 20 & & 80 & 5.2 & 2.5 \\
\hline W90-PV10-4M & 90 & 10 & 20 & & 80 & 5.2 & 2.5 \\
\hline W98-PV2-6M & 98 & 2 & & 20 & 80 & 5.8 & 2.3 \\
\hline W95-PV5-6M & 95 & 5 & & 20 & 80 & 5.8 & 2.3 \\
\hline W90-PV10-6M & 90 & 10 & & 20 & 80 & 5.8 & 2.3 \\
\hline
\end{tabular}

${ }^{1}$ wt. $\%$ respect to the total solid; ${ }^{2}$ wt. \% respect to the total liquid; ${ }^{3} \mathrm{Ms}$ of alkali-activator solution (molar ratio).

The preparation of the pastes started by mechanically stirring the $\mathrm{Na}_{2} \mathrm{SiO}_{3}$ and $\mathrm{NaOH}$ solution (mass ratio of 4:1) in a plastic beaker. The mixed precursors were then added gradually into the alkali-activated solution for $2 \mathrm{~min}$ at $568 \mathrm{rpm}$ to promote the dissolution of the reactive phases in the alkali media. Afterwards, the mixture was mixed for $3 \mathrm{~min}$ at $760 \mathrm{rpm}$. The pastes were poured into $25-\mathrm{mm}^{3}$ moulds that were sealed in plastic bags for three days in a climate chamber at $25 \pm 1{ }^{\circ} \mathrm{C}$ and with a relative humidity of $95 \pm 5 \%$. Finally, the specimens were demoulded after three days and kept in a climate chamber with the same conditions until the experiments (28 days). Nine cubic specimens were prepared for each formulation.

\subsection{Test Methods}

The hydrolytic stability of AA-WBA/PV was evaluated by using the boiling water test [18], which evaluates the resistance of the binders to degradation in water. One specimen for each formulation was first dried in a desiccator with silica gel to constant weight. The specimen was then placed in boiling water for $20 \mathrm{~min}$, before being dried again in a desiccator to constant weight. Later, visual analysis was conducted to verify the cohesion of the sample. Finally, the sample was weighed to calculate the weight loss percentage.

A selective chemical extraction was carried out to determine the main reaction products formed. The formation of calcium silicate hydrate (C-S-H), calcium aluminosilicate hydrate (C-A-S-H), and sodium aluminosilicate hydrate (N-A-S-H) gels after the alkali activation can be estimated from the calcium and aluminium contents of the precursors [39]. Salicylic acid/methanol (SAM) extraction can be used to determine the formation of the C-S-H and C-A-S-H phases [40]. SAM extraction consisted of mixing $1 \mathrm{~g}$ of the binder sample with salicylic acid $(6 \mathrm{~g})$ and methanol $(40 \mathrm{~mL})$ for $1 \mathrm{~h}$. The resulting solution was then filtered (Whatman filter paper with a $20-\mu \mathrm{m}$ pore size), and the residual fraction (RF) was washed and dried to constant weight in a desiccator with silica gel. The RF was weighed to calculate the mass dissolved percentage. Another selective chemical extraction test with $\mathrm{HCl}$ was performed to determine the formation of the C-S- $\mathrm{H}, \mathrm{C}-\mathrm{A}-\mathrm{S}-\mathrm{H}$, and N-A-S-H 
gels [39]. The extraction process consisted of stirring $1 \mathrm{~g}$ of the binder sample with $250 \mathrm{~mL}$ of the $\mathrm{HCl}$ solution (1:20) for $3 \mathrm{~h}$. Afterwards, the solution was filtered (Whatman filter paper with a $20-\mu \mathrm{m}$ pore size), and the weight loss percentage of the washed and dried RF was determined.

XRD analysis of the AA-WBA/PV formulations was performed using a Bragg-Brentano Siemens D-500 powder diffractometer (Siemens, Munich, Germany) with $\mathrm{CuK} \alpha$ radiation to identify the main crystalline phases. Fourier transform infrared spectroscopy (FT-IR) spectra of the AA-WBA/PV binders in the attenuated total reflectance (ATR) mode were obtained with a Spectrum Two ${ }^{\text {TM }}$ FT-IR spectrometer from PerkinElmer (PerkinElmer Inc., Waltham, MA, USA). Measurements were performed in the $4000-400 \mathrm{~cm}^{-1}$ range with a 32-scan average and a $4-\mathrm{cm}^{-1}$ resolution. FT-IR spectra deconvolution of the most representative samples in the $1200-800 \mathrm{~cm}^{-1}$ range was also performed. This range is associated with the symmetric and asymmetric stretching vibrations of the Si-O bonds [41]. The computer software Origin Pro 9 (OriginLab Corporation, Northampton, MA, USA) was used to fit and adjust the shape of the spectra with Gaussian functions, following some of the criteria from the literature [41]. Scanning electron microscopy with energy-dispersive X-ray spectroscopy (SEM-EDS) was used to evaluate the microstructure of the samples using an ESEM FEI Quanta 200 equipment (Thermo Fisher Scientific, Waltham, MA, USA). The samples were cut with a diamond disc cutter and coated with graphite.

Bulk density and open porosity tests were performed following the EN 1936:2006 standard. The compressive strength of the AA-WBA/PV formulations was determined following the UNE-EN 196-1 standard and using an Incotecnic MULTI-R1 device (Matest S.P.A., Bergamo, Italy) equipped with a $20-\mathrm{kN}$ load cell. Three cubic specimens were used in the physical and mechanical tests.

The WBA, PV, and AA-WBA/PV formulations were assessed to determine the leaching of heavy metalloids (As, Ba, Cd, $\mathrm{Cr}, \mathrm{Cu}, \mathrm{Hg}, \mathrm{Mo}, \mathrm{Pb}, \mathrm{Ni}, \mathrm{Sb}$, and $\mathrm{Zn}$ ) using an ELAN-6000 inductively coupled plasma mass spectrometer (ICP-MS) from PerkinElmer (PerkinElmer Inc., Waltham, MA, USA). Three replicates per sample (WBA, PV, and AA-WBA/PV) were used following the European EN 12457-2 standard. In the case of the AA-WBA/PV binders, the crushed specimens (smaller than $4 \mathrm{~mm}$ ) obtained after the compressive strength test were used.

\section{Results and Discussion}

\subsection{Hydrolitic Stability Test}

The boiling water test demonstrated that all the formulations of the AA-WBA/PV tested were resistant to degradation in water (Figure 4). Although some negligible defects were observed at the edges of the specimens, the visual analysis revealed that all the samples remained dimensionally unaltered. As shown in Figure $4 \mathrm{a}$, a layer of sodium carbonate efflorescence formed on the surface of the AA-WBA/PV specimens, which was removed after the test (Figure $4 \mathrm{~b}$ ). The weight loss percentage (below $1.5 \%$ in all cases) also confirmed the hydrolytic stability of the AA-WBA/PV binders, revealing the structural integrity of the samples, probably due to the formation of new reaction products.

\subsection{SAM and $\mathrm{HCl}$ Extraction}

The results from the selective chemical extractions are given in Table 3. The SAM extraction results demonstrated that the OPC paste was mainly composed of the C-S-H gel, as expected, while all the formulations of AA-WBA/PV contained C-S-H and C-A-S-H gels. The concentration of the alkaline activator solution had an effect, since AA-WBA/PV activated with $6 \mathrm{M} \mathrm{NaOH}$ solution showed a higher percentage of mass dissolved by the SAM extraction method. This was due to the higher $\mathrm{pH}$ of the alkaline activator solution, which increased the Ca content of the formed gel [42]. The SAM extraction results were not conclusive in determining the effect of varying the PV content, since there was no appreciable change in the percentage of mass dissolved by the SAM extraction method among the formulations activated with the same $\mathrm{NaOH}$ concentration. 


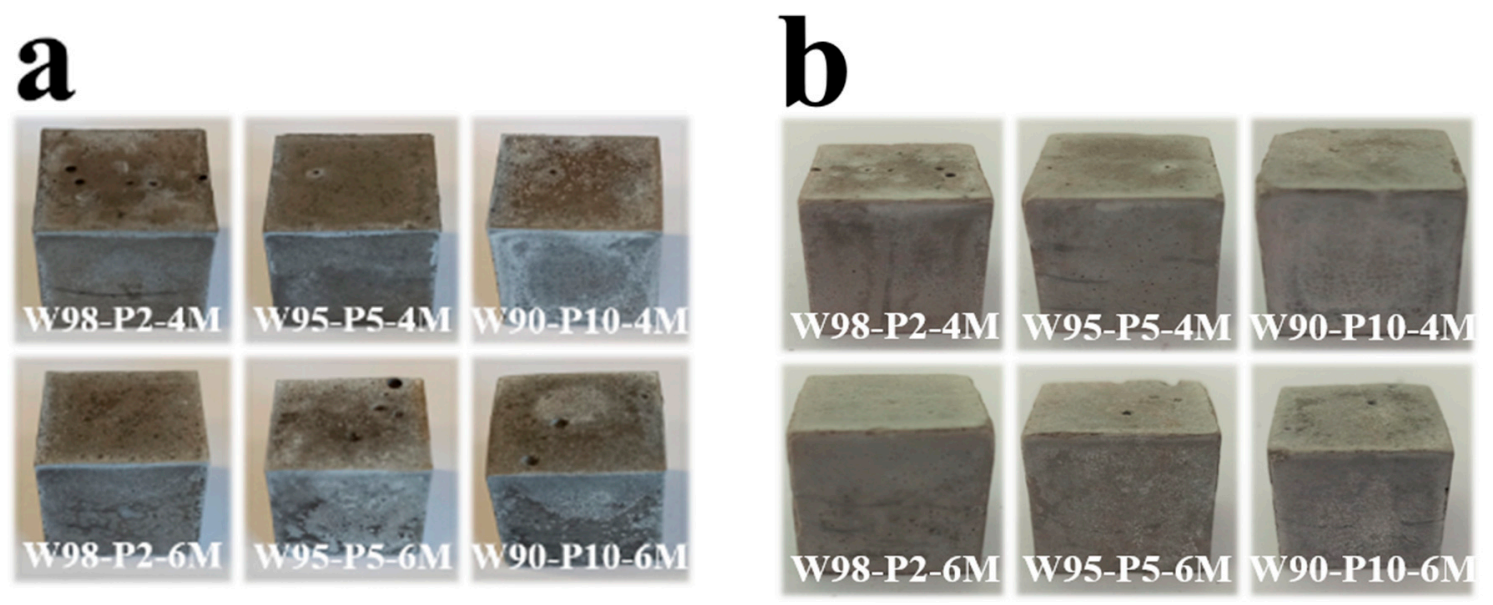

Figure 4. AA-WBA/PV specimens (a) before and (b) after the boiling test.

Table 3. Selective chemical extraction results.

\begin{tabular}{ccc}
\hline Samples & Mass Dissolved by SAM (wt. \%) & Mass Dissolved by HCl (wt. \%) \\
\hline OPC paste & 89.8 & - \\
WBA powder & 5.5 & 27.1 \\
PV powder & 6.5 & 30.4 \\
\hline W98-PV2-4M & 20.5 & 38.5 \\
W95-PV5-4M & 20.2 & 37.9 \\
W90-PV10-4M & 20.4 & 38.1 \\
\hline W98-PV2-6M & 22.8 & 39.1 \\
W95-PV5-6M & 23.3 & 39.6 \\
W90-PV10-6M & 23.1 & 39.0 \\
\hline
\end{tabular}

The $\mathrm{HCl}$ extraction results showed a slight increase in the percentage of mass dissolved for the formulations activated with $6 \mathrm{M} \mathrm{NaOH}$. There was no appreciable difference when varying the $\mathrm{PV}$ content, similar to that observed with the SAM extraction. The results on the percentages of mass dissolved for the WBA and PV regarding AA-WBA/PV demonstrated the formation of new reaction products in all the formulations of AA-WBA/PV. However, it is important to highlight that $\mathrm{HCl}$ extraction dissolves the main reaction products of $\mathrm{AABs}$ (C-S-H, C-A-S-H, and N-A-S-H gels) [39] and the other mineral phases (i.e., carbonate phases) of the precursors and the AA-WBA/PV binders [43]. Therefore, physicochemical characterization is necessary to confirm the formation of these new reaction products.

\subsection{Physicochemical Charaterization}

The crystalline phases found in the AA-WBA/PV binders are summarized in Table 4 . The presence of calcite, cristobalite, corundum, dolomite, gibbsite, and quartz was due to the unreacted WBA and PV. Calcium silicate hydrate as the main C-S-H phase and gismondine [44] and gehlenite [45] as the C-A-S-H phases were detected in all the AA-WBA/PV formulations. The presence of anorthite in the W98PV2 formulations and albite in all the formulations indicated the formation of (C,N)-A-S-H [46] and N-A-S-H [47] gels, respectively. Sodalite, which is associated with a zeolitic product [48,49], was also detected in all the XRD patterns. Kanemite, another typical phase of alkali-silica reaction products [50,51], was identified in the formulations activated with $6 \mathrm{M} \mathrm{NaOH}$. The XRD results are consistent with the SAM and $\mathrm{HCl}$ extraction results (Section 3.2) in demonstrating the formation of new reaction products (C-S-H, C-A-S-H, and (C,N)-A-S-H gels). 
Table 4. Crystalline phases in AA-WBA/PV binders.

\begin{tabular}{|c|c|c|c|c|c|c|c|}
\hline \multirow{3}{*}{ Identified Phase } & \multirow{3}{*}{ PDF } & \multicolumn{6}{|c|}{ Formulations } \\
\hline & & \multicolumn{3}{|c|}{$\mathrm{NaOH} 4 \mathrm{M}$} & \multicolumn{3}{|c|}{$\mathrm{NaOH} 6 \mathrm{M}$} \\
\hline & & W98PV2 & W95PV5 & W90PV10 & W98PV2 & W95PV5 & W90PV10 \\
\hline Albite & 01-083-1609 & $\mathrm{Y}$ & $\mathrm{Y}$ & $\mathrm{Y}$ & $\mathrm{Y}$ & $\mathrm{Y}$ & $\mathrm{Y}$ \\
\hline Calcite & 01-072-1937 & $\mathrm{Y}$ & $\mathrm{Y}$ & $\mathrm{Y}$ & $\mathrm{Y}$ & $\mathrm{Y}$ & Y \\
\hline Calcium Silicate Hydrate & 014-0035 & Y & $\mathrm{N}$ & $\mathrm{N}$ & $\mathrm{N}$ & $\mathrm{Y}$ & $\mathrm{N}$ \\
\hline Calcium Silicate Hydrate & 011-0507 & & Y & Y & Y & $\mathrm{N}$ & Y \\
\hline Cristobalite & 01-082-1479 & $\mathrm{Y}$ & $\mathrm{Y}$ & $\mathrm{Y}$ & $\mathrm{Y}$ & $\mathrm{Y}$ & $\mathrm{Y}$ \\
\hline Corundum & 01-071-1123 & & Y & Y & $\mathrm{N}$ & $\mathrm{Y}$ & Y \\
\hline Diopside & 01-071-1067 & & $\mathrm{Y}$ & $\mathrm{N}$ & $\mathrm{Y}$ & $\mathrm{Y}$ & $\mathrm{N}$ \\
\hline Dolomite & 01-079-1342 & $\mathrm{Y}$ & & $\mathrm{N}$ & $\mathrm{N}$ & $\mathrm{N}$ & $\mathrm{N}$ \\
\hline Gehlenite & 01-079-2422 & Y & $\mathrm{Y}$ & Y & Y & $\mathrm{Y}$ & Y \\
\hline Gibbsite & 01-076-1782 & $\mathrm{Y}$ & Y & $\mathrm{Y}$ & Y & Y & Y \\
\hline Gismondine & 020-0452 & $\mathrm{Y}$ & $\mathrm{Y}$ & $\mathrm{Y}$ & $\mathrm{Y}$ & $\mathrm{Y}$ & $\mathrm{Y}$ \\
\hline Kanemite & 025-1309 & & $\mathrm{N}$ & $\mathrm{N}$ & $\mathrm{Y}$ & $\mathrm{Y}$ & $\mathrm{Y}$ \\
\hline Quartz & 01-083-0539 & $\mathrm{Y}$ & $\mathrm{Y}$ & $\mathrm{Y}$ & $\mathrm{Y}$ & $\mathrm{Y}$ & $\mathrm{Y}$ \\
\hline Sodalite & 01-082-1811 & $\mathrm{Y}$ & $\mathrm{Y}$ & $\mathrm{Y}$ & $\mathrm{Y}$ & $\mathrm{Y}$ & $\mathrm{Y}$ \\
\hline
\end{tabular}

Figure 5 shows the results of the FT-IR analysis of the WBA and AA-WBA/PV formulations in the range of $1650-600 \mathrm{~cm}^{-1}$. There is a broad band $\left(1200-900 \mathrm{~cm}^{-1}\right)$ in all the spectra that is associated with the asymmetric $\mathrm{T}-\mathrm{O}(\mathrm{T}=\mathrm{Si}$ or $\mathrm{Al})$ stretching mode [41]. The change in the position and shape of this broad band in the AA-WBA/PV spectra regarding that of the WBA indicates alkali activation and the formation of new phases. The displacement of the broad band to higher frequencies in the AA-WBA/PV spectra, when compared to the WBA spectrum, demonstrates the formation of the C-S-H and C-A-S-H phases [52]. The broad band shifts to lower frequencies with increasing $\mathrm{NaOH}$ concentration and aluminium in the AA-WBA/PV spectra. This is probably due to the formation of the N-A-S-H phases [53] and the inclusion of aluminium in the C-S-H gel [54]. This agrees with the results from the selective chemical extractions (Section 3.2) and XRD analysis. There is a band at $785 \mathrm{~cm}^{-1}$ in all the spectra corresponding to the quartz contained in the WBA [53]. The other observed peaks are attributed to the stretching vibrations $(1405,1436$, and $1483 \mathrm{~cm}^{-1}$ ) and bending vibrations ( 875 and $713 \mathrm{~cm}^{-1}$ ) of calcium carbonates [55].

The deconvoluted FT-IR spectra in the range of $1200-800 \mathrm{~cm}^{-1}$ are shown in Figure 6. The W98PV2-4M and W90PV10-6M samples were selected as they had the lowest and highest $\mathrm{NaOH}$ concentration and aluminium content, respectively. The spectra present the same peaks that have slightly displaced to lower frequencies due to increases in the $\mathrm{NaOH}$ concentration and PV content. The main narrow band at $1016-1013 \mathrm{~cm}^{-1}$ and the band at $1144-1153 \mathrm{~cm}^{-1}$ are ascribed to the $v_{3}(\mathrm{Si}-\mathrm{O})$ bridging bond stretching vibrations [56]. The displacement of these bands to lower frequencies for the W90PV10-6M sample indicates a lower degree of polymerization of the silicate chains [41]. The two bands at $\approx 900$ and $\approx 866 \mathrm{~cm}^{-1}$ correspond to Si-O terminal bonds, indicating an incomplete polymerization of the gel [56]. Finally, the narrow peak at $875 \mathrm{~cm}^{-1}$ corresponds to calcium carbonate stretching vibrations (C-O). 
Figure 7 depicts the FT-IR spectra of the W98PV2-4M and W90PV10-6M samples before and after the selective chemical extractions. The shift and displacement of the broad band $\left(1009-1013 \mathrm{~cm}^{-1}\right)$ towards a higher frequency $\left(1064 \mathrm{~cm}^{-1}\right)$ indicates the dissolution of the C-S-H, C-A-S-H, and (C,N)-A-S-H phases. The dissolution of these phases produced three characteristic peaks that indicate the presence of silica gel $\left(790,945\right.$, and $\left.1064 \mathrm{~cm}^{-1}\right)$ [57]. $\mathrm{HCl}$ extraction completely dissolved the calcium carbonate peaks associated with the stretching vibrations (1405 and $\left.1448 \mathrm{~cm}^{-1}\right)$ and bending vibrations $\left(875\right.$ and $\left.713 \mathrm{~cm}^{-1}\right)$. In the case of SAM extraction, some peaks in the spectra are diffused (713 and $1448 \mathrm{~cm}^{-1}$ ) or remain equal $\left(875 \mathrm{~cm}^{-1}\right)$.

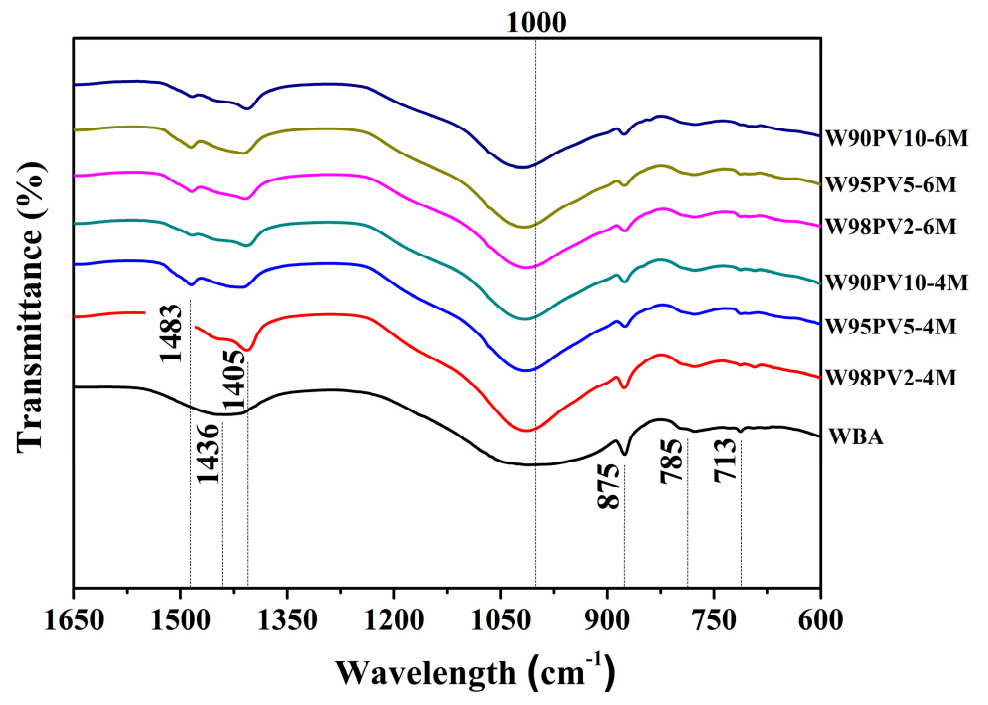

Figure 5. FT-IR spectra of WBA and AA-WBA/PV.

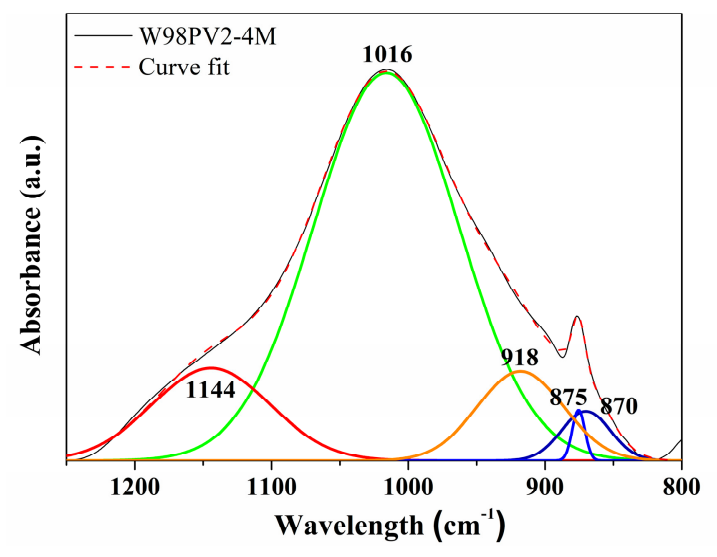

(a)



(b)

Figure 6. FT-IR deconvoluted spectra of (a) the W98PV2-4M sample and (b) W90PV10-6M sample. 


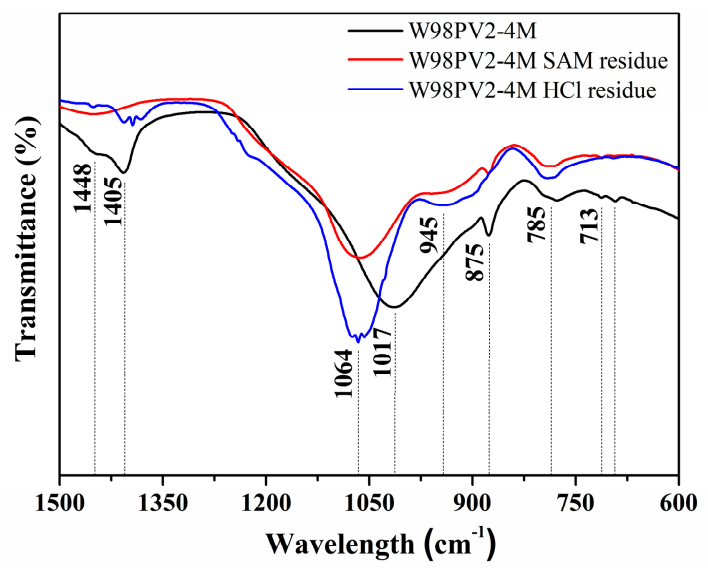

(a)

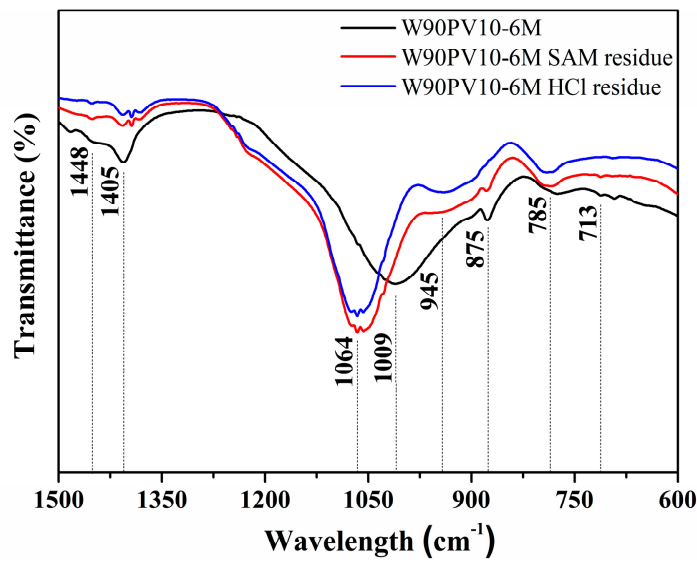

(b)

Figure 7. FT-IR spectra after selective chemical extractions: (a) W98PV2-4M sample and (b) W90PV10-6M sample.

SEM micrographs obtained in the backscattered electron (BSE) mode of the W98PV2-4M and W90PV10-6M samples are depicted in Figure 8. There was a substantial difference in the compactness of the samples. The W98PV2-4M sample presented a homogeneous dark greyish compact matrix with some small spherical pores (darkest zones) and unreacted particles. Microcracks could also be observed throughout the sample, indicating drying shrinkage during the curing process [58]. The W90PV10-6M sample presented higher porosity than the W98PV2-4M sample. Increasing the PV content and $\mathrm{NaOH}$ concentration in the W90PV10-6M formulation increased the aluminium nitride (AIN) content and alkaline activator concentration, respectively. As mentioned before, the reaction between $\mathrm{AlN}$ and $\mathrm{NaOH}$ produces ammonia gas, which is mainly responsible for generating the porosity of AA-WBA/PV [38].

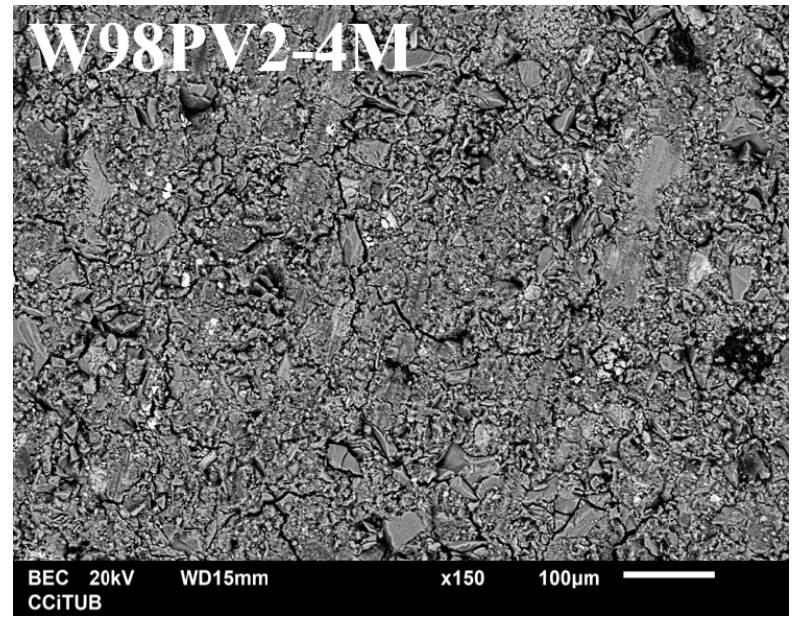

(a)

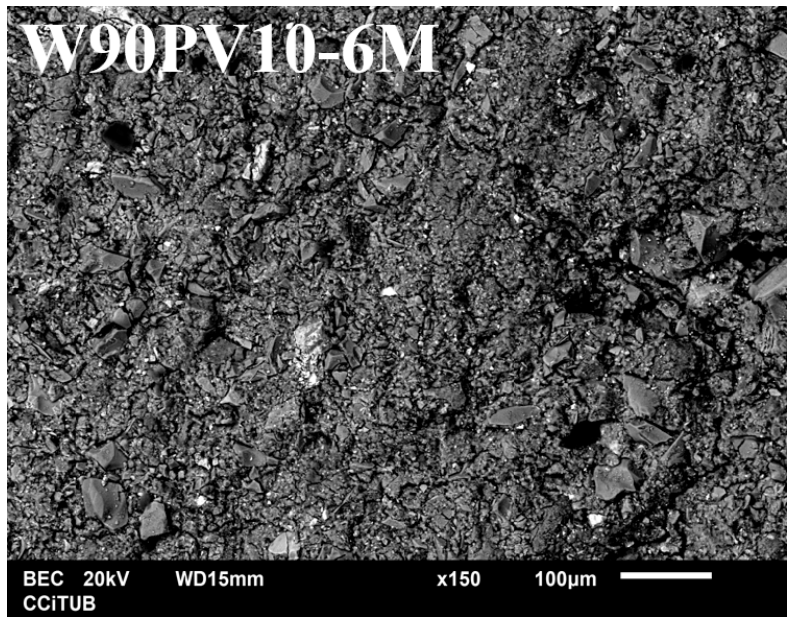

(b)

Figure 8. SEM images of (a) W98PV2-4M sample and (b) W90PV10-6M sample.

\subsection{Physical and Mechanical Properties}

The bulk density and open porosity of the AA-WBA/PV binders are shown in Figure 9, which demonstrates the influence of the PV content and $\mathrm{NaOH}$ concentration on these properties. As mentioned in Section 3.3, increasing the PV content and $\mathrm{NaOH}$ concentration promotes porosity, which implies a decrease in the bulk density. The open porosity curves in Figure 9 also show the porosity-enhancing effect of the PV content and $\mathrm{NaOH}$ concentration 
when increased, as demonstrated by the pronounced slope for the samples formulated with $6 \mathrm{M} \mathrm{NaOH}$.



Figure 9. Bulk density and open porosity of AA-WBA/PV binders.

Compressive strength (Figure 10) decreased with increasing PV content and $\mathrm{NaOH}$ concentration, which agrees with the physical properties of the samples. The substantial difference between the W98PV2-4M and W90PV10-6M samples demonstrated the negative effect of increased porosity on the mechanical properties of the AA-WBA/PV binders.

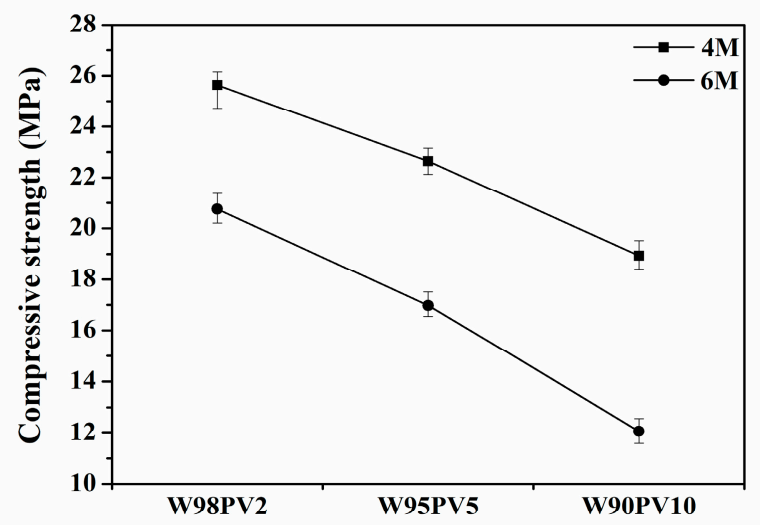

Figure 10. Compressive strength of AA-WBA/PV binders.

\subsection{Environmental Characterization}

Leaching tests in deionized water were conducted following the EN 12457-2 standard to simulate the environmental impact of the AA-WBA/PV binders when they are demolished at the end of their useful life. The concentrations of the heavy metals and metalloids leaching from the WBA, PV, and AA-WBA/PV binders, as well as the limits for acceptance in waste landfills [59], are summarized in Table 5. For the WBA, only the $\mathrm{Sb}$ concentration exceeded the limit for inert waste. For the PV powder, Mo and $\mathrm{Sb}$ concentrations exceeded the limits for inert waste and non-hazardous waste, respectively. The results for the AA-WBA/PV binders varied substantially depending on the heavy metals and metalloids. Mo and $\mathrm{Pb}$ concentrations were above the limit for non-hazardous waste. However, the main issue was the high activation of metalloids (As and $\mathrm{Sb}$ ) in the AA-WBA/PV binders regarding the WBA and PV. Indeed, the leaching concentrations of $\mathrm{As}$ and $\mathrm{Sb}$ exceeded the limits for acceptance at landfills for non-hazardous waste. The immobilization of these two metalloids is hampered by the high $\mathrm{pH}$ environment during the alkali activation process, which contributes to their anionic formation [60]. However, an increase in immobilization efficiency after 18 months of curing has been reported in the literature [61]. Therefore, the immobilization of As and $\mathrm{Sb}$ in the AA-WBA/PV matrix is expected to improve with longer curing times comparable to the lifecycle of these materi- 
als. The primary and secondary glass contents of the WBA are the main contributors of the metalloids in AA-WBA/PV [31]. Sb and As oxides are used in the glass industry as refining and coloring agents [62] and are mainly found in the coarse fraction of WBA [17]. Furthermore, $\mathrm{Sb}$ is also found in $\mathrm{PV}$, because this metal is used in the aluminum industry as a modifier of the eutectic structure and as a grain refiner [63]. Increasing the $\mathrm{NaOH}$ concentration affected the leaching of the metalloids from the AA-WBA/PV formulations. The higher the concentration of the alkaline activator solution, the higher the concentration of the leaching metalloids. However, the effect of increasing the PV content was negligible.

Table 5. Leaching concentrations $\left(\mathrm{mg} \cdot \mathrm{kg}^{-1}\right)$ in WBA, PV, and AA-WBA/PV binders after leaching tests (EN 12457-2) and limits for acceptance at landfills.

\begin{tabular}{|c|c|c|c|c|c|c|c|c|c|c|c|c|}
\hline Sample & As & $\mathbf{B a}$ & $\mathrm{Cd}$ & $\mathrm{Cr}$ & $\mathrm{Cu}$ & $\mathrm{Hg}$ & Mo & $\mathrm{Ni}$ & $\mathbf{P b}$ & $\mathrm{Sb}$ & $\mathrm{Zn}$ & $\mathrm{pH}$ \\
\hline WBA & 0.02 & 0.25 & $<0.01$ & 0.17 & 0.69 & 0.01 & 0.33 & 0.11 & 0.01 & 0.27 & 0.12 & 9.54 \\
\hline PV & 0.10 & 0.06 & $<0.01$ & 0.01 & 0.15 & $<0.01$ & 2.90 & $<0.20$ & 0.01 & 1.38 & 0.10 & 10.03 \\
\hline W98-PV2-4M & 2.44 & 0.14 & $<0.01$ & 0.12 & 0.54 & 0.04 & 0.42 & $<0.20$ & 0.44 & 2.82 & 0.76 & 11.61 \\
\hline W95-PV5-4M & 2.45 & 0.16 & $<0.01$ & 0.14 & 0.50 & 0.02 & 0.50 & $<0.20$ & 0.54 & 2.86 & 0.71 & 11.59 \\
\hline W90-PV10-4M & 2.34 & 0.31 & $<0.01$ & 0.14 & 0.55 & 0.01 & 0.72 & $<0.20$ & 0.49 & 2.86 & 0.51 & 11.48 \\
\hline W98-PV2-6M & 2.78 & 0.15 & $<0.01$ & 0.05 & 0.53 & 0.01 & 0.52 & $<0.20$ & 0.55 & 3.15 & 0.54 & 11.63 \\
\hline W95-PV5-6M & 2.77 & 0.19 & $<0.01$ & 0.18 & 0.81 & 0.06 & 0.50 & $<0.20$ & 0.52 & 3.22 & 0.68 & 11.57 \\
\hline W90-PV10-6M & 2.68 & 0.22 & $<0.01$ & 0.24 & 0.34 & 0.02 & 0.70 & $<0.20$ & 0.50 & 3.18 & 0.80 & 11.57 \\
\hline${ }^{1}$ Inert waste $\left(\mathrm{mg} \cdot \mathrm{kg}^{-1}\right)$ & 0.5 & 20 & 0.04 & 0.5 & 2 & 0.01 & 0.5 & 0.4 & 0.5 & 0.06 & 4 & \\
\hline $\begin{array}{c}{ }^{1} \text { Non-hazardous waste } \\
\qquad\left(\mathrm{mg} \cdot \mathrm{kg}^{-1}\right)\end{array}$ & 2 & 100 & 1 & 10 & 50 & 0.2 & 10 & 10 & 10 & 0.7 & 50 & \\
\hline $\begin{array}{c}{ }^{1} \text { Hazardous waste } \\
\left(\mathrm{mg} \cdot \mathrm{kg}^{-1}\right)\end{array}$ & 25 & 300 & 5 & 70 & 100 & 2 & 30 & 40 & 50 & 5 & 200 & \\
\hline
\end{tabular}

${ }^{1}$ limit for acceptance in landfills [59].

\section{Conclusions}

The use of WBA and PV in the formulation of AABs can lead to a low-carbon and zero-waste manufacturing of cement. This study demonstrated the potential of the coarse fraction of WBA and PV as silica-rich and alumina-rich precursors, respectively. The AA-WBA/PV binders remain stable after immersion in boiling water due to the formation of new phases. Selective chemical extractions, XRD analysis, and FT-IR analysis revealed the presence of C-S-H, C-A-S-H, and/or (N,C)-A-S-H gels as the main reaction products formed in the AA-WBA/PV binders. The $\mathrm{NaOH}$ concentration and PV content influenced the mechanical and physical properties of the binders. Increasing the $\mathrm{NaOH}$ concentration and the PV content increased the formation of the reaction products as well as porosity. Increasing the PV content, however, reduced the compressive strength of the binders. These results reflect the versatility of PV when applied to enhance mechanical properties or used as an aerating agent to improve thermal conductivity. Finally, the environmental impact of the binders was assessed with leaching tests, which revealed that a high $\mathrm{pH}$ of the alkaline activator solution increased the leaching of metalloids from AA-WBA/PV. Considering that the main goal of this study was to obtain AABs with good mechanical properties, W98PV2-4M is the optimal formulation, with the lowest metalloid leaching potential.

Author Contributions: A.M.-A.: conceptualization, formal analysis, investigation, writing-original draft, review and editing; J.M.: formal analysis, investigation, writing-review and editing; J.G.-P.: conceptualization, supervision, validation, writing - review and editing; J.F.: funding acquisition, validation, writing - review and editing; J.M.C.: conceptualization, supervision, validation, funding acquisition. All authors have read and agreed to the published version of the manuscript.

Funding: This research was partially funded by the Spanish Government (BIA2017-83912-C2-1-R). Alex Maldonado-Alameda and Jofre Mañosa are grateful to the Catalan Government for their research Grants, FI-DGR 2017 and FI-2020, respectively. 
Institutional Review Board Statement: Not applicable.

Informed Consent Statement: Not applicable.

Acknowledgments: The authors would like to thank the Catalan Government for the quality accreditation given to their research groups DIOPMA (2017 SGR 118). Authors also want to thank BEFESA S.A. company for supplying the PAVAL ${ }^{\circledR}$ and to SIRUSA and VECSA for supplying the MSWI Bottom Ash. Jessica Giro-Paloma is a Serra Húnter Fellow.

Conflicts of Interest: The authors declare no conflict of interest.

\section{References}

1. Song, Q.; Li, J.; Zeng, X. Minimizing the increasing solid waste through zero waste strategy. J. Clean. Prod. 2015, 104, 199-210. [CrossRef]

2. Mohanty, C.R.C. Reduce, reuse and recycle (the 3Rs) and resource efficiency as the basis for sustainable wate management. In Proceedings of the Synergizing Resource Efficiency with Informal Sector towards Sustainable Waste Management, New York, NY, USA, 9 May 2011; pp. 1-31.

3. Zaman, A.U. A comprehensive review of the development of zero waste management: Lessons learned and guidelines. J. Clean. Prod. 2015, 91, 12-25. [CrossRef]

4. Singh, S.; Ramakrishna, S.; Gupta, M.K. Towards zero waste manufacturing: A multidisciplinary review. J. Clean. Prod. 2017, 168, 1230-1243. [CrossRef]

5. Eurostat-European Statistical Office Municipal Waste by Waste Management Operations Statistics. Available online: https: / / appsso.eurostat.ec.europa.eu/nui/submitViewTableAction.do (accessed on 23 March 2020).

6. Eurostat-European Statistical Office Generation of Waste by Waste Category. Available online: https: / / appsso.eurostat.ec.europa. $\mathrm{eu} /$ nui/show.do?dataset=env_wasgen\&lang=en (accessed on 3 April 2020).

7. Dou, X.; Ren, F.; Nguyen, M.Q.; Ahamed, A.; Yin, K.; Chan, W.P.; Chang, V.W.C. Review of MSWI bottom ash utilization from perspectives of collective characterization, treatment and existing application. Renew. Sustain. Energy Rev. 2017, 79, 24-38. [CrossRef]

8. Stabile, P.; Bello, M.; Petrelli, M.; Paris, E.; Carroll, M.R. Vitrification treatment of municipal solid waste bottom ash. Waste Manag. 2019, 95, 250-258. [CrossRef]

9. CEWEP-Confederation of European Waste-to-Energy Bottom Ash Fact Sheet. 2019, pp. 1-2. Available online: https://www. cewep.eu/wp-content/uploads/2017/09/FINAL-Bottom-Ash-factsheet.pdf (accessed on 3 April 2020).

10. Xuan, D.; Tang, P.; Poon, C.S. Limitations and quality upgrading techniques for utilization of MSW incineration bottom ash in engineering applications-A review. Constr. Build. Mater. 2018, 190, 1091-1102. [CrossRef]

11. Chimenos, J.M.; Fernández, A.I.; Nadal, R.; Espiell, F. Short term natural weathering of MSWI bottom ash. J. Hazard. Mater. B79 2000, 79, 287-299. [CrossRef]

12. Zhang, H.; Shimaoka, T. Formation of Humic Substances in Weathered MSWI Bottom Ash. Sci. World J. 2013, 2013, 384806. [CrossRef]

13. Li, X.-G.; Lv, Y.; Ma, B.-G.; Chen, Q.-B.; Yin, X.-B.; Jian, S.-W. Utilization of municipal solid waste incineration bottom ash in blended cement. J. Clean. Prod. 2012, 32, 96-100. [CrossRef]

14. Saikia, N.; Cornelis, G.; Mertens, G.; Elsen, J.; Van Balen, K.; Van Gerven, T.; Vandecasteele, C. Assessment of Pb-slag, MSWI bottom ash and boiler and fly ash for using as a fine aggregate in cement mortar. J. Hazard. Mater. 2008, 154, 766-777. [CrossRef]

15. Ginés, O.; Chimenos, J.M.; Vizcarro, A.; Formosa, J.; Rosell, J.R. Combined use of MSWI bottom ash and fly ash as aggregate in concrete formulation: Environmental and mechanical considerations. J. Hazard. Mater. 2009, 169, 643-650. [CrossRef] [PubMed]

16. Silva, R.V.; de Brito, J.; Lynn, C.J.; Dhir, R.K. Environmental impacts of the use of bottom ashes from municipal solid waste incineration: A review. Resour. Conserv. Recycl. 2019, 140, 23-35. [CrossRef]

17. Maldonado-Alameda, A.; Giro-Paloma, J.; Svobodova-Sedlackova, A.; Formosa, J.; Chimenos, J.M. Municipal solid waste incineration bottom ash as alkali-activated cement precursor depending on particle size. J. Clean. Prod. 2020, 242, 1-10. [CrossRef]

18. Zhu, W.; Chen, X.; Struble, L.J.; Yang, E.H. Characterization of calcium-containing phases in alkali-activated municipal solid waste incineration bottom ash binder through chemical extraction and deconvoluted Fourier transform infrared spectra. J. Clean. Prod. 2018, 192, 782-789. [CrossRef]

19. Zhu, W.; Chen, X.; Struble, L.J.; Yang, E.H. Quantitative characterization of aluminosilicate gels in alkali-activated incineration bottom ash through sequential chemical extractions and deconvoluted nuclear magnetic resonance spectra. Cem. Concr. Compos. 2019, 99, 175-180. [CrossRef]

20. Shi, C.; Jiménez, A.F.; Palomo, A. New cements for the 21st century: The pursuit of an alternative to Portland cement. Cem. Concr. Res. 2011, 41, 750-763. [CrossRef]

21. Bernal, S.A.; Rodríguez, E.D.; Kirchheim, A.P.; Provis, J.L. Management and valorisation of wastes through use in producing alkali-activated cement materials. J. Chem. Technol. Biotechnol. 2016, 91, 2365-2388. [CrossRef]

22. Provis, J.L.; Van Deventer, J.S.J. Alkali Activated Materials; Provis, J.L., Van Deventer, J.S.J., Eds.; Springer: New York, NY, USA, 2014; Volume 1, ISBN 978-94-007-7671-5.

23. McLellan, B.C.; Williams, R.P.; Lay, J.; Van Riessen, A.; Corder, G.D. Costs and carbon emissions for geopolymer pastes in comparison to ordinary portland cement. J. Clean. Prod. 2011, 19, 1080-1090. [CrossRef] 
24. Duxson, P.; Provis, J.L.; Lukey, G.C.; van Deventer, J.S.J. The role of inorganic polymer technology in the development of "green concrete". Cem. Concr. Res. 2007, 37, 1590-1597. [CrossRef]

25. Rovnaník, P. Effect of curing temperature on the development of hard structure of metakaolin-based geopolymer. Constr. Build. Mater. 2010, 24, 1176-1183. [CrossRef]

26. Fernández-Jiménez, A.; Puertas, F. Effect of activator mix on the hydration and strength behaviour of alkali-activated slag cements. Adv. Cem. Res. 2003, 15, 129-136. [CrossRef]

27. Li, C.; Sun, H.; Li, L. A review: The comparison between alkali-activated slag $(\mathrm{Si}+\mathrm{Ca})$ and metakaolin $(\mathrm{Si}+\mathrm{Al})$ cements. Cem . Concr. Res. 2010, 40, 1341-1349. [CrossRef]

28. Fernández-Jiménez, A.; Palomo, A.; Sobrados, I.; Sanz, J. The role played by the reactive alumina content in the alkaline activation of fly ashes. Microporous Mesoporous Mater. 2006, 91, 111-119. [CrossRef]

29. Duxson, P.; Mallicoat, S.W.; Lukey, G.C.; Kriven, W.M.; van Deventer, J.S.J. The effect of alkali and Si/Al ratio on the development of mechanical properties of metakaolin-based geopolymers. Colloids Surf. A Physicochem. Eng. Asp. 2007, 292, 8-20. [CrossRef]

30. García-Lodeiro, I.; Cherfa, N.; Zibouche, F.; Fernández-Jimenez, A.; Palomo, A. The role of aluminium in alkali-activated bentonites. Mater. Struct. Constr. 2014, 48, 585-597. [CrossRef]

31. Del Valle-Zermeño, R.; Gómez-Manrique, J.; Giro-Paloma, J.; Formosa, J.; Chimenos, J.M. Material characterization of the MSWI bottom ash as a function of particle size. Effects of glass recycling over time. Sci. Total Environ. 2017, 581-582. [CrossRef]

32. Maldonado-Alameda, A.; Mañosa, J.; Giro-Paloma, J.; Formosa, J.; Chimenos, J.M. Alkali-activated binders based on the coarse fraction of municipal solid waste incineration bottom ash. Bol. Soc. Esp. Ceram. Vidr. 2021, in press.

33. Leiva, C.; Luna-Galiano, Y.; Arenas, C.; Alonso-Fariñas, B.; Fernández-Pereira, C. A porous geopolymer based on aluminum-waste with acoustic properties. Waste Manag. 2019, 95, 504-512. [CrossRef]

34. Befesa Reciclaje de Escorias Salinas. 2002. Available online: https://www.befesa.com/export/sites/befesa2014/resources/pdf/ accionistas_e_inversores/informe_anual/2002/2002_4a.pdf (accessed on 3 April 2020).

35. IECA Beneficios del uso del PAVAL para la Fabricación de Cementos. 2014. Available online: https://www.ieca.es/producto/ beneficios-del-uso-del-paval-la-fabricacion-cementos / (accessed on 3 April 2020).

36. Maldonado-Alameda, À.; Giro-Paloma, J.; Alfocea-Roig, A.; Formosa, J.; Chimenos, J.M. Municipal Solid Waste Incineration Bottom Ash as Sole Precursor in the Alkali-Activated Binder Formulation. Appl. Sci. 2020, 10, 4129. [CrossRef]

37. Ruiz-Santaquiteria, C.; Fernández-Jiménez, A.; Palomo, A. Quantitative determination of reactive $\mathrm{SiO}_{2}$ and $\mathrm{Al}_{2} \mathrm{O}_{3}$ in aluminosilicate materials. In Proceedings of the 13th International Congress on the Chemistry of Cement, Madrid, Spain, 6 July 2011; pp. 1-7.

38. Bajare, D.; Bumanis, G.; Korjakins, A. New Porous Material Made from Industrial and Municipal Waste for Building Application. Mater. Sci. 2014, 20, 3-8. [CrossRef]

39. Puligilla, S.; Mondal, P. Co-existence of aluminosilicate and calcium silicate gel characterized through selective dissolution and FTIR spectral subtraction. Cem. Concr. Res. 2015, 70, 39-49. [CrossRef]

40. García Lodeiro, I.; Macphee, D.E.; Palomo, A.; Fernández-Jiménez, A. Effect of alkalis on fresh C-S-H gels. FTIR analysis. Cem. Concr. Res. 2009, 39, 147-153. [CrossRef]

41. Ping, Y.; Kirkpatrick, R.J.; Brent, P.; McMillan, P.F.; Xiandong, C. Structure of Calcium Silicate Hydrate (C-S-H): Near-, Mid-, and Far-Infrared Spectroscopy. J. Am. Ceram. Soc. 1999, 82, 742-748.

42. García-Lodeiro, I.; Fernández-Jiménez, A.; Blanco, M.T.; Palomo, A. FTIR study of the sol-gel synthesis of cementitious gels: C-S-H and N-A-S-H. J. Sol-Gel Sci. Technol. 2008, 45, 63-72. [CrossRef]

43. Taylor, H.F.W. Cement Chemistry, 2nd ed.; Thomas Telford Ltd.: London, UK, 1997; ISBN 978-0-7277-3945-2.

44. Lancellotti, I.; Ponzoni, C.; Barbieri, L.; Leonelli, C. Alkali activation processes for incinerator residues management. Waste Manag. 2013, 33, 1740-1749. [CrossRef]

45. Huang, G.; Ji, Y.; Zhang, L.; Li, J.; Hou, Z. The influence of curing methods on the strength of MSWI bottom ash-based alkali-activated mortars: The role of leaching of $\mathrm{OH}$ and free alkali. Constr. Build. Mater. 2018, 186, 978-985. [CrossRef]

46. Park, S.M.; Jang, J.G.; Lee, N.K.; Lee, H.K. Physicochemical properties of binder gel in alkali-activated fl y ash/slag exposed to high temperatures. Cem. Concr. Res. 2016, 89, 72-79. [CrossRef]

47. Huang, G.; Ji, Y.; Li, J.; Zhang, L.; Liu, X.; Liu, B. Effect of activated silica on polymerization mechanism and strength development of MSWI bottom ash alkali-activated mortars. Constr. Build. Mater. 2019, 201, 90-99. [CrossRef]

48. Eun, J.; Monteiro, P.J.M.; Sun, S.; Choi, S.; Clark, S.M. The evolution of strength and crystalline phases for alkali-activated ground blast furnace slag and fly ash-based geopolymers. Cem. Concr. Res. 2010, 40, 189-196.

49. Querol, X.; Moreno, N.; Umaña, J.C.; Alastuey, A.; Hernández, E.; López-Soler, A.; Plana, F. Synthesis of zeolites from coal fly ash: An overview. Int. J. Coal Geol. 2002, 50, 413-423. [CrossRef]

50. Shi, Z.; Geng, G.; Leemann, A.; Lothenbach, B. Synthesis, characterization, and water uptake property of alkali-silica reaction products. Cem. Concr. Res. 2019, 121, 58-71. [CrossRef]

51. Noguchi, N.; Kajio, T.; Morinaga, Y.; Elakneswaran, Y.; Nawa, T. Impact of Portlandite on Alkali-Silica Reaction of Pyrex Glass and Blastfurnace Slag Aggregate. In Proceedings of the Sixth International Conference on Durability of Concrete Structures, Leeds, UK, 18 July 2018; pp. 267-272.

52. Puertas, F.; Fernández-Jiménez, A.; Blanco-Varela, M.T. Pore solution in alkali-activated slag cement pastes. Relation to the composition and structure of calcium silicate hydrate. Cem. Concr. Res. 2004, 34, 139-148. [CrossRef] 
53. Fernández-Jiménez, A.; Palomo, A. Mid-infrared spectroscopic studies of alkali-activated fly ash structure. Microporous Mesoporous Mater. 2005, 86, 207-214. [CrossRef]

54. Walkley, B.; San Nicolas, R.; Sani, M.A.; Rees, G.J.; Hanna, J.V.; van Deventer, J.S.J.; Provis, J.L. Phase evolution of C-(N)-A-S$\mathrm{H} / \mathrm{N}-\mathrm{A}-\mathrm{S}-\mathrm{H}$ gel blends investigated via alkali-activation of synthetic calcium aluminosilicate precursors. Cem. Concr. Res. 2016, 89, 120-135. [CrossRef]

55. Li, N.; Farzadnia, N.; Shi, C. Microstructural changes in alkali-activated slag mortars induced by accelerated carbonation. Cem. Concr. Res. 2017, 100, 214-226. [CrossRef]

56. Criado, M.; Fernández-Jiménez, A.; Palomo, A. Alkali activation of fly ash: Effect of the $\mathrm{SiO}_{2} / \mathrm{Na}_{2} \mathrm{O}$ ratio. Part I: FTIR study. Microporous Mesoporous Mater. 2007, 106, 180-191. [CrossRef]

57. Zhu, W.; Chen, X.; Zhao, A.; Struble, L.J.; Yang, E.H. Synthesis of high strength binders from alkali activation of glass materials from municipal solid waste incineration bottom ash. J. Clean. Prod. 2019, 212, 261-269. [CrossRef]

58. Rashad, A.M.; Sadek, D.M.; Hassan, H.A. An investigation on blast-furnace stag as fine aggregate in alkali-activated slag mortars subjected to elevated temperatures. J. Clean. Prod. 2016, 112, 1086-1096. [CrossRef]

59. Council of the European Union. Council Decision Establishing Criteria and Procedures for the Acceptance of Waste at Landfills Pursuant to Article 16 of and Annex II to Directive 1999/31/EC; European Union: Brussels, Belgium, 2003; pp. $27-49$.

60. Kiventerä, J.; Sreenivasan, H.; Cheeseman, C.; Kinnunen, P.; Illikainen, M. Immobilization of sulfates and heavy metals in gold mine tailings by sodium silicate and hydrated lime. J. Environ. Chem. Eng. 2018, 6, 6530-6536. [CrossRef]

61. Lancellotti, I.; Catauro, M.; Dal, F.; Kiventer, J.; Leonelli, C.; Illikainen, M. Alkali activation as new option for gold mine tailings inertization. J. Clean. Prod. 2018, 187, 76-84.

62. Apostoli, P.; Giusti, S.; Bartoli, D.; Perico, A.; Bavazzano, P.; Alessio, L. Multiple exposure to arsenic, antimony, and other elements in art glass manufacturing. Am. J. Ind. Med. 1998, 34, 65-72. [CrossRef]

63. Taylor, P.; Barzani, M.M.; Farahany, S.; Yusof, N.M.; Ourdjini, A.; Barzani, M.M.; Farahany, S.; Yusof, N.M.; Ourdjini, A. The Influence of Bismuth, Antimony, and Strontium on Microstructure, Thermal, and Machinability of Aluminum-Silicon Alloy The Influence of Bismuth, Antimony, and Strontium on Microstructure, Thermal, and Machinability of Aluminum-Silicon Alloy. Mater. Manuf. Process. 2013, 28, 1184-1190. 